\title{
ANALISIS LAPORAN KEUANGAN RUMAH SAKIT BERDASARKAN KMK NOMOR 1981 TAHUN 2010 PADA RSUD CIMACAN
}

\section{ANALYSIS OF FINANCIAL STATEMENTS PURSUANT TO KMK NUMBER 1981 YEAR 2010 AT RSUD CIMACAN}

\author{
M.N. Afif, M. Yusuf \\ Program Studi Akuntansi Fakultas Ekonomi Universitas Djuanda Bogor \\ Jl. Tol Ciawi No. 1, Kotak Pos 35, Kode Pos 16720, Telp/Fax : (0251) 8245155 \\ E-mail : m.nur.afif @unida.ac.id, muhammad.yusuf@unida.ac.id
}

\begin{abstract}
This research was intended to determine the application in presentation of financial statements RSUD Cimacan full PPK-BLUD status with reference to the decree of the Minister of health (KMK) number 1981/MENKES/SK/XII/2010 about accounting guidelines of hospital public service agencies approved by Minister of finance number S-5342/MK.5/2010. Data analysis is qualitative descriptive with comparative method that is compare the application and presentation of financial statements prepared by RSUD Cimacan with financial statement based on KMK Number 1981 Year 2010. Complete components of financial statements comprise the balance sheet, operational reports, cash flow statements and notes to financial statements. The results showed that the presentation of financial statements of RSUD Cimacan full BLUD status generally has been in accordance with KMK Number 1981 Year 2010 in representation of financial statements, but have yet to present a cash flow statement based Government Accounting Standarts (SAP) according PP Number 71 Year 2010 for financial reporting entity in terms of consolidation, as well as a need for interested parties.
\end{abstract}

Keywords : PPK-BLUD, KMK Number 1981 Year 2010, Financial statements

\begin{abstract}
ABSTRAK
Penelitian ini bertujuan untuk mengetahui penerapan dalam penyajian laporan keuangan RSUD Cimacan berstatus PPK-BLUD penuh dengan mengacu pada keputusan Menteri Kesehatan No.1981 Tahun 2010 Tentang Pedoman Akuntansi Badan Layanan Umum-Rumah Sakit disetujui oleh Menteri Keuangan No.S-5342/MK.5/2010. Analisis data bersifat deskriptif kualitatif dengan metode komparatif yaitu membandingkan penerapan atas penyajian informasi laporan keuangan yang telah disusun RSUD Cimacan dengan laporan keuangan berdasarkan KMK No.1981 Tahun 2010. Komponen lengkap laporan keuangan terdiri dari neraca, laporan operasional, arus kas, dan CaLK. Hasil penelitian menunjukan bahwa penyajian atas laporan keuangan RSUD Cimacan berstatus BLUD penuh secara garis besar telah sesuai dengan KMK No.1981 Tahun 2010 dalam menyajikan laporan keuangan, namun belum menyajikan laporan arus kas berbasis standar akuntansi pemerintah (SAP) yang disesuaikan dengan PP No. 71/2010 untuk entitas pelaporan dalam keuangan untuk hal konsolidasi, juga sebagai kebutuhan untuk pihak berkepentingan.
\end{abstract}

Kata kunci : PPK-BLUD, KMK Nomor 1981 Tahun 2010, Laporan keuangan 


\section{PENDAHULUAN}

Badan Layanan Umum muncul setelah ditetapkannya Undang-Undang No. 1/2004 pasal ke-1 ayat 23 menyatakan bahwa Badan Layanan Umum adalah instansi yang berada di lingkungan pemerintah yang dibentuk untuk memberikan pelayanan kepada masyarakat berupa penyediaan barang dan/atau jasa yang dijual dengan tidak mencari keuntungan serta dalam melakukan kegiatan berdasarkan prinsip efisiensi dan produktifitas. Pengertian BLU kemudian diadopsi pada pasal ke- 1 ayat 1 PP No. 23/2005 tentang pengelolaannya. Tujuan dari BLU untuk meningkatkan pelayanan pada masyarakat sehingga dapat mencerdaskan masyarakat dan memajukan kesejahteraan semua kalangan dalam memberikan fleksibilitas dan pengelolaan keuangan didasarkan atas penerapan bisnis yang sehat dan prinsip ekonomi. Penetapan rumah sakit dalam lembaga pemerintahan untuk menerapkan BLU diharapkan dapat meningkatkan akuntabilitas serta transparansi dalam bidang kesehatan.

Perkembangan rumah sakit sebagai BLU menjadi acuan pemerintah daerah untuk menjadikan rumah sakit daerah sebagai BLUD. Permendagri No. 61/2007 membahas pedoman teknis dalam pengelolaan keuangan BLUD menyatakan pada pasal ke- 1 ayat 1 yang menjelaskan pengertian BLUD sebagai intansi pemerintah daerah yang memberikan pelayanan terhadap masyarakat baik berupa jasa atau barang dengan tidak mencari keuntungan berdasarkan produktifitas dan prinsip efisiensi. PPK-BLUD menerapkan kegiatan bisnis/usaha yang sehat sehingga dapat meningkatkan pelayanan kesehatan terhadap masyarakat untuk pengelolaan informasi keuangan daerah.

RSUD yang berubah status PPK-BLUD bukan merubah kepemilikan dan badan hukum. Badan hukum RSUD masih merupakan sebuah LTD dan kepemilikan tetap dalam pengelolaan pemerintah daerah, hanya saja pola pengelolaan keuangannya berubah menggunakan prinsip-prinsip BLUD.

Dalam UU No. 12/2011 pada pasal ke-7 ayat 1 menjelaskan peraturan perundangundangan sesuai jenis dan hierarkinya yang terdiri atas : 1). UUD 1945; 2). Ketetapan MPR; 3). UU; 4). Peraturan Presiden; 5). Peraturan Daerah Propinsi dan 6). Peraturan Daerah Kabupaten/Kota. Terbitnya Undang-Undang yang menempati posisi ke-3, maka secara pembenaran tidak beralasan untuk tidak menerapkan aturan dan ketentuan PPK-BLUD. Undang-Undang No. 44/2009 merupakan hukum dalam bentuk Undang-Undang hasil pembahasan DPR dan pemerintah.

Penegasan bahwa rumah sakit harus menjalankan Pola Pengelolaan Keuangan-BLU dalam UU No. 44/2009 menjelaskan tentang rumah sakit terdapat pada pasal ke- 7 ayat 3 menyatakan rumah sakit pemerintah daerah atau pemerintah pusat yang didirikan harus dalam bentuk unit pelaksana teknis pada instansi di bidang kesehatan, instansi tertentu, atau LTD dengan pengelolaan BLU ataupun BLUD dengan ketentuan peraturan atas perundang-undangan". Dipertegas lagi pada pasal ke-20 ayat 3 yang menyatakan rumah sakit publik yang dikelola oleh pemerintah baik pemerintah pusat ataupun daerah diselenggarakan atas dasar pengelolaan BLU ataupun BLUD sesuai dengan aturan dan ketentuan atas perundang-undangan. Penerapan PPK-BLUD pada SKPD ataupun dalam unit kerja harus memenuhi persyaratan substantif, teknis, dan administratif.(Sumber : http://mashani77.net)

Adapun dalam penentuan status BLUD dalam Permendagri No. 61 Tahun 2007 dalam pengelolaan BLUD terhadap keuangannya terbagi menjadi :

1. PPK BLUD Penuh dimana meningkatnya status dari PPK BLUD bertahap menjalankan PPK BLUD penuh.

2. BLUD bertahap dimana menurunnya status dari PPK BLUD penuh menerapkan PPK BLUD bertahap.

3. Kembalinya status satuan kerja atau unit kerja biasa dimana dicabutnya status baik dari PPK BLUD penuh maupun bertahap.

RSUD Cimacan merupakan rumah sakit berstatus BLUD penuh setelah ditetapkan tahun 2011, maka laporan keuangan yang tersaji oleh rumah sakit mengikuti BLU penuh dalam KMK No. 1981 Tahun 2010 sebagai pedoman akuntansi dalam penyajian dan penerapan laporan keuangan bagian BLU penuh. Penetapan BLUD dilakukan perlima tahun, apabila semua persyaratan telah sesuai maka BLUD akan bertahan secara penuh, akan tetapi apabila persyaratan tidak terpenuhi bisa jadi kemungkinan statusnya akan menurun menjadi BLUD bertahap. Laporan keuangan RSUD Cimacan secara organisasi belum diaudit oleh pihak auditor independen tetapi untuk 
hal konsolidasi dan pelaporan di Pemerintah Daerah Cianjur telah dilakukan audit oleh pihak BPK (Badan Pemeriksa Keuangan), dimana laporan konsolidasi dari entitas pelaporan di Kabupaten Cianjur digabungkan oleh Pemerintah Daerah. RSUD Cimacan secara individual belum diaudit oleh pihak auditor terhadap laporan keuangan dikarenakan merasa cukup dengan BPK yang mengaudit pemda. RSUD Cimacan seharusnya mengajukan untuk laporan keuangannya diaudit. SPI (Satuan Pemeriksa Internal) juga terbatas dengan adanya tenaga profesional di RSUD kurang memadai dengan jumlah tenaga kerja oleh 8 orang bagian keuangan terdiri atas 3 orang PNS dan 5 orang non PNS dari jumlah

Tabel 1: Perkembangan Penyajian Laporan Keuangan RSUD Cimacan Tahun 2011-2015

\begin{tabular}{|c|c|c|}
\hline No & 'ahun & Penyajian Laporan Keuangan sesuai BLU/BLUD \\
\hline 1 & 2011 & Penetapan BLUD dengan penilaian kinerja keuangan \\
\hline 2 & & 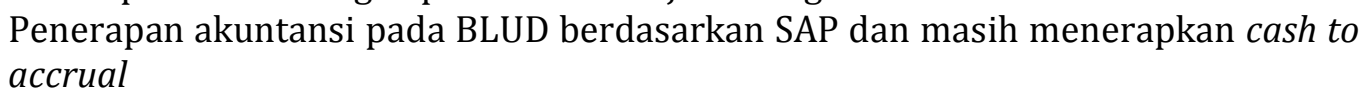 \\
\hline 3 & 2013 & bangan akuntansi berdasarkan SAP dan masih \\
\hline 4 & 2014 & $\begin{array}{l}\text { isarkan SAP, menerapkan akuntansi berdasarkan SAK, } \\
\text { sis }\end{array}$ \\
\hline 5 & 2015 & $\begin{array}{l}\text { Penerapan akuntansi accrual basis berdasarkan pada SAK dan SAP dalam } \\
\text { BLU/BLUD }\end{array}$ \\
\hline
\end{tabular}

Sumber : PPK-BLUD RSUD Cimacan, 2017.

Setiap lembaga pemerintahan

mempunyai standar, aturan dan acuan dalam menjalankan kinerjanya seperti dari Rosnidah, dkk (2016) menjelaskan dalam mengidentifikasi eksisting sistem akuntansi BLUD pada RSUD Waled, Cirebon yang menerapkan aturan PPK-BLUD berdasarkan "Permendagri Nomor 61 paragraf 116 tahun 2007 menjelaskan tentang BLUD harus menyajikan laporan keuangan basis akrual bahwa RSUD Waled sudah menerapkan PPKBLUD terhadap penyusunan laporan keuangannya tetapi belum merapkan basis akrual dan berpedoman pada SAK belum menggunakan SAP", maka dari itu RSUD Cimacan dibebankan menyusun laporan keuangan sesuai SAP pada PP No. 71 Tahun 2010 dan SAK ETAP dalam penyajiannya untuk dilaporkan ke pemda.

Penelitian terdahulu dari Widiastutik, dkk (2015) menganalisis penerapan PSAK No. 45 dan PMK No. 76/PMK.05/2008 di unit bisnis griya brawijaya di Universitas Brawijaya berstatus BLU dengan hasil penelitian bahwa sebagian masih relevan dan sebagian masih perlu perbaikan untuk menerapkan laporan
347 orang ketenagaan kerja dalam RSUD Cimacan.

Laporan keuangan RSUD berstatus BLU disusun untuk dapat menyediakan informasi terkait dengan posisi keuangan, kinerja keuangan dan perubahan terhadap keuangan. Penerapan akuntansi terhadap laporan keuangan RSUD Cimacan sebagai BLUD penuh dari 2011 s/d 2015 mengalami peningkatan dan perbaikan dalam penyusunan, penerapan dan penyajian terhadap laporan keuangan. Perkembangan laporan keuangan PPK-BLUD berbasis SAK dan SAP dapat dilihat sebagai tolak ukur pengembangan rumah sakit seperti pada tabel berikut: keuangan berdasarkan penyajian akuntansi keuangan BLU atau sektor publik pemerintah serta Santi dan Rosita (2009) untuk mengetahui kendala PPK-BLU dengan hasil menunjukan kendala utama implementasi PK BLU adalah perubahan mindset lama ke mindset baru dan permasalahan lainnya disebabkan hal administratif karena belum adanya atau belum jelasnya peraturan. Juga penelitian dari Eriotis, et al. (2009) menilai penerapan akuntansi accrual basis di RSU (Rumah Sakit Umum) Yunani dengan studi empiris.

Hasil menunjukkan pada tingkat penerapan akuntansi pada kualitas keuangan, perubahan sistem terkait pelatihan, tingkat pendidikan akuntansi dan konsultan professional berpengaruh positif. Namun, tidak adanya hubungan signifikan dengan ukuran rumah sakit, pelaksanaan perubahan biaya, latar belakang pendidikan, pengalaman, dan manajemen dokter. Sumbangan penelitian yaitu menyediakan pendekatan dan proses terhadap pemerintah Yunani untuk menerapkan akuntansi keuangan basis akrual dan akuntansi biaya dalam Greek National 
Health System (GNHS) dan peran tertentu dari faktor manusia, organisasi dan menempatkan situasional dalam implementasi tersebut.

Dalam penerapan dan pengembangan BLUD berdasarkan sistem akuntansi sebagaimana diatur pada Peraturan Pemerintah No. 23/2005 menjelaskan pengelolaan keuangan BLU, maka perlu diatur tentang ketentuan mengenai pedoman dan pelaporan pada keuangan BLUD dan menurut Permendagri No. 61/2007 pasal ke-116 ayat 1 menyatakan bahwa BLUD menyelenggarakan akuntansi dan laporan keuangan atas dasar SAK yang diterbitkan oleh asosiasi profesi akuntansi Indonesia untuk kegiatan bisnis yang sehat. Berdasarkan pertimbangan inilah Menteri Kesehatan menetapkan KMK RI No. 1981/MENKES/SK/XII/2010, maka penyusunan, penyajian dan penerapan laporan keuangan RSUD Cimacan yang telah berstatus BLUD, dimana RSUD merupakan objek Menteri Kesehatan harus menerapkan peraturan tersebut sebagai pedoman dan acuan untuk pengembangan akuntansi yang menyesuaikan dengan BLU-RS.

\section{METODE PENELITIAN}

Objek penelitian dari penelitian ini adalah RSUD Cimacan yang bertempat di Jalan Cipanas No. 17 Cimacan Kecamatan Cipanas, Kabupaten Cianjur, Provinsi Jawa Barat. Penelitian ini adalah penelitian bersifat deskriptif dengan kualitatif yang dapat memberikan gambaran tentang latar belakang objek penelitian, sifat-sifat dan karakteristik dari subjek yang diteliti. Penelitiannya menunjukan penelitian non hipotesis, sehingga dalam langkah penelitian tidak perlu membuat rumusan hipotesis. Jenis data penelitian yang didapatkan berupa data subjek (Subject data) yaitu jenis data yang berupa sikap, opini, pengalaman, karakteristik dan seseorang atau sekelompok orang yang menjadi subjek penelitian dan data dokumenter (Document data) yaitu laporan keuangan RSUD Cimacan tahun 2016.

Data-data dalam penelitian yang dianalisis, antara lain :

1. Neraca

2. Laporan aktivitas/operasional

3. Laporan arus kas

4. CaLK (catatan atas laporan keuangan)

Adapun sumber datayang digunakan terdapat dua jenis sumber data antara lain data primer merupakan data subjek yang didapat secara langsung dari sumber penelitian yang memerlukan pengolahan lanjutan oleh penulis yang diperoleh dari hasil wawancara peneliti dengan pihak terkait. Selanjutnya, data sekunder merupakan data yang telah diolah bersumber dari instansi sebagai objek penelitian yang sudah diolah dan didokumentasi.

\section{Analisis Data}

Penelitian menggunakan deskriptif kualitatif dengan metode komparatif yaitu dilakukan dengan cara membandingkan penerapan akuntansi dalam kebijakan akuntansi maupun penyusunan, penyajian dan penerapan laporan keuangan RSUD Cimacan berdasarkan KMK No. 1981/2010 sebagai pedoman akuntansi Badan Layanan UmumRumah Sakit (BLU-RS). Metode komparatif digunakan untuk membandingkan perbedaan dan persamaan dari fakta-fakta, sifat-sifat dan karakteristik dari objek berdasarkan kerangka pemikiran yang telah dibuat. Hal ini untuk membandingkan standar yang ada dengan kegiatan dari praktek yang ditemui pada BLUD RSUD Cimacan.

Teknik yang dipergunakan dalam melakukan penelitian sebagai berikut:

1. Mengumpulkan data tentang penyajian dan penerapan laporan keuangan RSUD Cimacan yang diteliti dengan cara mengantarkan surat izin penelitian, mewawancara pihak BLUD RSUD Cimacan, menggali informasi tentang penggunaan standar akuntansi, mengetahui perkembangan penyajian dalam penerapan laporan keuangan sejak ditetapkan BLUD tahun 2011 sampai 2015 dan meminta data terkait penelitian.

2. Menganalisis data dengan cara membuat tabel yang berisi laporan keuangan yang tersaji pada RSUD Cimacan, membandingkan laporan keuangan menurut KMK No. 1981 tahun 2010 dalam penyajiannya, sesuai atau tidak dengan alat analisis KMK Nomor 1981/2010 yang digunakan.

3. Membandingkan data yang didapat dengan teori atau alat analisis mengenai ketentuan laporan keuangan BLU-RS dengan membandingkan laporan keuangan RSUD Cimacan dalam pencatatan, pengakuan dan 
penyajian serta penerapan akuntansi sesuai KMK No. 1981 Tahun 2010.

4. Mendeskripsikan tabel laporan keuangan RSUD Cimacan yang dibuat, apakah telah sesuai atau belum dalam penerapan akuntansi yang meliputi neraca, laporan aktivitas/operasional, arus kas dan CaLK dengan KMK Nomor 1981/2010 sebagai pedoman akuntansi BLU-RS.

5. Menarik kesimpulan penelitian yang telah dilakukan terhadap laporan keuangan RSUD Cimacan telah sesuai atau belum dengan KMK Nomor 1981/2010 disertai penjelasan.

Analisis untuk melakukan perbandingan apakah format penyajian sesuai KMK No. 1981 Tahun 2010 sebagai pedoman akuntansi pada rumah sakit berstatus BLU atau perlu penyesuaian kembali. Apabila laporan keuangan telah sesuai ketentuan-ketentuan yang terdapat didalam KMK No. 1981 Tahun 2010 sebagai pedoman dan acuan akuntansi dalam BLU rumah sakit, maka penyajian tersebut adalah benar. Sebaliknya, apabila laporan keuangan belum sesuai dengan aturan KMK No. 1981 Tahun 2010 sebagai pedoman dan acuan akuntansi dalam BLU rumah sakit, maka penyajian akuntansi tersebut adalah salah dan perlu penyesuaian.

\section{HASIL DAN PEMBAHASAN}

CaLK RSUD Cimacan tahun 2016 menerangkan bahwa kebijakan akuntansi pemerintah daerah adalah prinsip-prinsip, dasar-dasar, konvensi-konvensi, aturanaturan, dan praktik-pratik yang dipilih pemda sebagai pedoman dalam menyusun, menerapkan dan menyajikan laporan

Tabel 2: Perbandingan Neraca Tentang Penyajian Laporan Keuangan Menurut RSUD Cimacan dan Menurut KMK No. 1981 Tahun 2010

\begin{tabular}{|c|c|c|c|c|}
\hline \multirow[t]{2}{*}{ No } & \multirow{2}{*}{$\begin{array}{c}\text { Penyajian Laporan Keuangan } \\
\text { menurut KMK }\end{array}$} & \multirow{2}{*}{$\begin{array}{l}\text { Penyajian Laporan Keuangan menurut } \\
\text { RSUD Cimacan }\end{array}$} & \multicolumn{2}{|c|}{ Hasil } \\
\hline & & & Sesuai & $\begin{array}{l}\text { Tidak } \\
\text { Sesuai }\end{array}$ \\
\hline 1 & $\begin{array}{l}\text { Kas atau setara kas merupakan } \\
\text { pos/akun yang disajikan paling } \\
\text { lancar (likuid) dan lazim pada } \\
\text { urutan pertama unsur aset }\end{array}$ & $\begin{array}{l}\text { Kas atau setara kas disajikan pada } \\
\text { posisi pertama dalam neraca diukur } \\
\text { dan dicatat sesuai nilai nominal. Nilai } \\
\text { nominal disajikan sebesar nilai } \\
\text { rupiahnya, Apabila kas dalam bentuk } \\
\text { valuta asing harus dikonversi kedalam } \\
\text { rupiah dengan menggunakan kurs } \\
\text { tengah berdasarkan BI pada tanggal } \\
\text { neraca }\end{array}$ & $\checkmark$ & \\
\hline 2 & $\begin{array}{l}\text { Investasi lancar/jangka pendek } \\
\text { bentuk deposito disajikan pada } \\
\text { golongan pos aset lancar di }\end{array}$ & $\begin{array}{l}\text { Investasi jangka pendek disajikan } \\
\text { pada golongan aset lancar sesuai } \\
\text { nominal investasi yang bisa segera }\end{array}$ & $\checkmark$ & \\
\hline
\end{tabular}

keuangan untuk memenuhi kebutuhan pemakai laporan keuangan dalam meningkatkan keterbandingan terhadap anggaran, baik antar periode maupun antar entitas. Basis akuntansi adalah basis akrual dimana pengeluaran dan penerimaan diakui atau dicatat ketika transaksi telah terjadi, bukan saat kas untuk transaksi diterima atau dibayarkan. Penyusunan, penyajian dan penerapan laporan keuangan tahun 2016 mengacu pada SAP yang ditetapkan sesuai PP No. 71/2010 (Pergantian dari PP No. 24/2005) dan SAK ETAP untuk kepentingan pihak lain yang terkait. RSUD Cimacan menggunakan aplikasi SIMDA dari pemerintah daerah dalam pencatatan dan penyusunan laporan keuangannya.

Laporan keuangan yang disajikan secara lengkap merupakan unsur penting laporan keuangan yang disajikan. KMK RI No. 1981/MENKES/SK/XII/2010 menjelaskan pedoman akuntansi dalam BLU-RS bahwa ada 4 komponen laporan keuangan yang secara lengkap untuk disajikan Antara lain neraca, laporan aktivitas/operasional, laporan arus kas serta CaLK. Perbandingan atau metode komparatif yang dilakukan untuk mengetahui sudah sesuaikah laporan keuangan RSUD berstatus BLUD penuh dengan aturan KMK No. 1981/2010 sebagai pedoman dan acuan akuntansi pada rumah sakit berstatus BLU, lebih jelasnya akan disajikan tabel perbandingan sesuai dengan data yang didapat serta hasil wawancara dengan bagian keuangan BLUD RSUD Cimacan dapat dilihat pada tabel yang disajikan.

\section{Neraca}

\section{Penyajian Laporan Keuangan Penyajian Laporan Keuangan}


neraca sesuai nilai nominal, apabila investasi lancar lebih dari satu tahun maka akan disajikan dineraca pada investasi jangka panjang

3 Piutang disajikan pada golongan pos aset lancar di neraca sesuai jumlah neto, sedangkan piutang lain-lain yang telah jatuh tempo satu tahun lebih disajikan dalam golongan aset non lancar serta piutang pelayanan dan piutang lain-lain disajikan pada pos yang terpisah

4 Persediaan disajikan pada golongan aset lancar sebesar nilai perolehan

5 Beban dibayar dimuka pada aset lancar disajikan sebesar jumlah neto

6 Aset tetap berdasarkan nilai perolehan untuk disajikan dikurangi dengan akumulasi penyusutan dan tanah disajikan sebesar harga perolehan sebagai aset tetap

7 Aset tidak berwujud disajikan sebagai aset sebesar biaya perolehannya dikurangi dengan akumulasi rugi penurunan nilai dan akumulasi amortisasinya

8 Aset lainnya disajikan pada golongan pos aset lainnya secara terpisah dicairkan dan dimaksudkan

kepemilikan selama 12 (dua belas) bulan atau kurang dari 12 bulan serta disajikan di neraca investasi jangka panjang melebihi satu tahun investasi Piutang atau piutang lainnya disajikan pada golongan pos aset lancar sebesar nilai yang belum dibayar/dilunasi tetapi belum secara piutang bersih $\mathrm{s} / \mathrm{d}$ tanggal pelaporan dari setiap tagihan sesuai surat ketetapan kurang bayar yang telah diterbitkan atau setiap tagihan yang telah ditetapkan terutang oleh pengadilan pajak terhadap wajib pajak dalam mengajukan banding atau setiap tagihan yang masih dalam proses banding terhadap keberatan dan majelis tuntutan ganti rugi yang belum menetapkan

Persediaan disajikan pada golongan aset lancar sebesar harga perolehan akhir atau harga pokok produksi akhir atau nilai wajar

Beban dibayar dimuka pada pos aset lancar disajikan sesuai jumlah neto

Aset tetap dan bagian aset tetap disajikan sesuai harga perolehan dikurangi dengan akumulasi penyusutan dan dinilai sesuai biaya perolehan. Apabila aset tetap dinilai berdasar biaya perolehan yang tidak memungkinkan maka aset tetap dinilai atas dasar nilai wajar pada saat perolehan aset

Aset tidak berwujud disajikan sebagai aset sebesar biaya perolehannya adalah aset secara fisik tidak berwujud atau tidak daapat dinyatakan secara fisik serta dimiliki untuk dapat menghasilkan jasa atau barang atau digunakan dengan tujuan lainnya termasuk Haki (Hak atas kekayaan intelektual)

Aset lainnya disajikan dan dicatat sebagai aset yang tidak dapat dikelompokkan pada aset tak berwujud seperti tuntutan perbendaharaan, tuntutan penjualan angsuran, tuntutan ganti rugi, tuntutan perbendaharaan dan kemitraan dengan pihak ketiga 


Kewajiban lancar dalam
neraca yang disajikan terdiri
dari : pendapatan diterima
dimuka, beban yang harus
dibayar, utang usaha, utang
pajak, utang muka pasien dan
utang lain-lain dan apabila
terdapat akun lain dapat
dibentuk pos tersendiri

10 Kewajiban jangka panjang sesuai dengan biaya perolehan yang diamortisasi untuk disajikan dan kewajiban jangka panjang direklasifikasikan kedalam kewajiban jangka pendek apabila telah jatuh tempo

11 Ekuitas dalam neraca disajikan sebesar saldo ekuitasnya dan dirinci berdasarkan jenis ekuitas

\begin{abstract}
Kewajiban lancar diklasifikasikan juga kewajiban jangka pendek jika jatuh tempo dalam 12 bulan serta disajikan sesuai akun-akun yang dibentuk sesuai pos-pos tersendiri yang terdapat di neraca
\end{abstract}

Kewajiban jangka panjang disajikan sesuai biaya perolehan akibat dari dilakukannya pembiayaan oleh pemerintah daerah dalam menutup defisit anggarannya atau semua kewajiban Pemda yang waktunya lebih dari 12 bulan jatuh tempo sejak tanggal pelaporan

Ekuitas disajikan sesuai saldo ekuitas yang merupakan hasil selisih dari aset dan kewajiban daerah

Sumber : Data hasil olahan, 2017

Berdasarkan tabel 2 menjelaskan tentang penyajian neraca laporan keuangan 2016 yang disusun oleh RSUD Cimacan sesuai aturan standar dalam KMK No. 1981 Tahun 2010 hanya saja dalam penyajian piutang yang secara neto dengan akun penyisihan piutang dalam penyajian neracanya belum secara piutang bersih. Dalam KMK No. 1981/2010 menyebutkan bahwa piutang dalam neraca disajikan pada golongan pos aset lancar sebesar jumlah neto atau piutang bersih, sedangkan piutang lain-lain yang telah jatuh tempo lebih dari 12 bulan disajikan pada

golongan aset non lancar, piutang pelayanan dan piutang lain-lain disajikan pada pos-pos yang terpisah. Dijelaskan pula, dalam CaLK RSUD Cimacan tahun 2016 saldo piutang lainlain pendapatan anggaran daerah yang sah merupakan piutang yang sampai 31 Desember 2016 belum dilunasi sebesar Rp 2.597.702.400,- terdiri dari piutang pelayanan pasien BPJS dan pelayanan pasien Jamkesda/SKTM. Rekapitulasi piutang dan penyisihan piutang yang tak tertagih dapat dilihat dalam tabel 3 berikut :

Tabel 3: Rekapitulasi Piutang lain-lain dan Penyisihan Piutang yang Tidak Tertagih

\begin{tabular}{ccccc}
\hline Tahun & Jumlah Piutang & Umur Piutang & Prosentase & $\begin{array}{c}\text { Jumlah Penyisihan Piutang } \\
\text { yang Tidak Tertagih }\end{array}$ \\
\hline Piutang RSUD Cimacan & & & $31.917 .809,50$ \\
\hline 2016 & $2.400 .690 .700,00$ & $>1$ bulan & $10 \%$ & $985.058,50$ \\
\hline Jumlah & $197.011 .700,00$ & 1 bulan & $0,5 \%$ & $32.902 .868,00$ \\
\hline
\end{tabular}

Sumber : CaLK RSUD Cimacan, 2016.

Dari hasil perhitungan piutang tak tertagih, maka piutang sesuai dengan nilai nominal yang dapat tertagih (Nilai realisasi bersih/NRV) dapat disajikan sehingga apabila berdasarkan CaLK RSUD Cimacan tahun 2016 maka piutang berdasarkan umur piutang yang disajikan seharusnya sesuai nilai bersih/neto untuk dimasukan kedalam neraca RSUD Cimacan tahun 2016 sebesar Rp 2.564.799.532,00 sedangkan yang disajikan neraca RSUD Cimacan tahun 2016 sebesar Rp 2.400.690.700,00 serta penyisihan piutang yang seharusnya Rp 32.902.868,00 disajikan Rp 31.917.809,50. Perbedaan antara neraca dengan CaLK mengenai penjelasan tentang pos neraca seharusnya disajikan sejumlah dengan piutang bersih untuk ditagih, padahal RSUD Cimacan sudah menjelaskan dalam CaLKnya mengenai piutang bersih. Rekapitulasi NRV 
(Net Realizable Value) untuk piutang lain-lain dapat dilihat di tabel 4 berikut:

Tabel 4: Rekapitulasi Piutang Bersih (NRV)

\begin{tabular}{lrrr}
\hline Uraian & Piutang Lain-Lain & Penyisihan Piutang & Piutang Bersih (NRV) \\
\hline RSUD Cimacan & $2.597 .702 .400,00$ & $(32.902 .868,00)$ & $2.564 .799 .532,00$ \\
Jumlah & $2.597 .702 .400,00$ & $(32.902 .868,00)$ & $2.564 .799 .532,00$ \\
\hline
\end{tabular}

Sumber : CaLK RSUD Cimacan, 2016.

Berdasarkan penjelasan yang diuraikan, piutang pada neraca RSUD Cimacan 2016 masih sesuai dengan peraturan standar yang ditetapkan oleh KMK Nomor 1981/2010, hanya saja yang dimasukan dalam piutang neracanya tidak sesuai nominal dengan piutang bersih (NRV) yang dijelaskan dalam

CaLK laporan keuangan RSUD Cimacan tahun 2016. Keseluruhan RSUD Cimacan sudah menerapkan neraca dengan pedoman dan aturan akuntansi BLU rumah sakit.

\section{Laporan Operasional/Aktivitas}

Tabel 5 :Perbandingan Laporan Aktivitas/Operasional dalam Penyajian Laporan Keuangan Menurut RSUD Cimacan dan Menurut KMK No. 1981 Tahun 2010

\begin{tabular}{|c|c|c|c|c|}
\hline \multirow[t]{2}{*}{ No } & \multirow{2}{*}{$\begin{array}{l}\text { Penyajian Laporan keuangan } \\
\text { menurut KMK }\end{array}$} & \multirow{2}{*}{$\begin{array}{l}\text { Penyajian Laporan Keuangan } \\
\text { Menurut RSUD Cimacan }\end{array}$} & \multicolumn{2}{|c|}{ Hasil } \\
\hline & & & Sesuai & $\begin{array}{l}\text { Tidak } \\
\text { Sesuai }\end{array}$ \\
\hline 1 & $\begin{array}{ll}\text { Pendapatan secara } & \text { terpisah } \\
\text { disajikan pada laporan } & \text { aktivitas } \\
\text { atau laporan operasional } & \end{array}$ & $\begin{array}{l}\text { Pendapatan disajikan secara terpisah } \\
\text { dalam bagian pos-pos pendapatan }\end{array}$ & $\checkmark$ & \\
\hline 2 & $\begin{array}{l}\text { Beban disajikan secara kelompok } \\
\text { tersendiri sebagai pengurang } \\
\text { pendapatan }\end{array}$ & $\begin{array}{l}\text { Beban-beban disajikan tersendiri } \\
\text { sesuai kelompok bagiannya dan } \\
\text { pengurang }\end{array}$ & $\checkmark$ & \\
\hline 3 & $\begin{array}{l}\text { Laporan aktivitas/operasional } \\
\text { mencantumkan surplus/defisit } \\
\text { sebelum pos dan tahun berjalan }\end{array}$ & $\begin{array}{l}\text { Laporan aktivitas atau operasional } \\
\text { RSUD Cimacan mencantumkan } \\
\text { surplus/defisit sebelum pos dan } \\
\text { tahun berjalan }\end{array}$ & $\checkmark$ & \\
\hline
\end{tabular}

Sumber : Data hasil olahan, 2017.

Berdasarkan tabel 5 yang telah dianalisis secara keseluruhan RSUD Cimacan telah menyajikan laporan operasional atau laporan aktivitas sesuai dengan pedoman standar akuntansi pada BLU-RS. Jumlah saldo pendapatan asli daerah-LO di RSUD Cimacan s/d 31 Desember 2016 sebesar Rp 19.477.435.808,-. Pendapatan secara terpisah untuk disajikan diantaranya pendapatan pajak daerah-LO,pendapatan dari hasil pengelolaan

kekayaan daerah dipisahkan-LO, pendapatan retribusi daerah-LO, dan lain-lain. Pendapatan menjadi tolak ukur tercapainya kinerja instansi pemerintahan dalam bidang pengelolaan keuangannya, sedangkan saldo beban RSUD Cimacan Cianjur tahun 2016 sebesar Rp 39.029.689.834,-. Komposisi saldo beban RSUD Cimacan Cianjur tahun 2016 tersaji pada tabel 6 sebagai berikut:

Tabel 6: Komposisi Saldo Beban

\begin{tabular}{llrr}
\hline \multirow{2}{*}{ NO } & \multicolumn{2}{c}{ URAIAN } & \multicolumn{2}{c}{ JUMLAH } \\
& & $3.573 .063 .501,00$ & $4.082 .023 .302,00$ \\
\hline 1 & Beban Pegawai & 0,00 & 0,00 \\
2 & Beban Persediaan & $18.656 .836 .370,00$ & $9.118 .344 .072,00$ \\
3 & Beban Barang dan Jasa & 0,00 & 0,00 \\
4 & Beban Pemeliharaan & 0,00 & 0,00 \\
5 & Beban Perjalanan Dinas & $16.757 .927 .115,00$ & $9.492 .791 .390,00$ \\
6 & Beban Penyusutan dan Amortisasi & $32.902 .868,00$ & $88.085 .226,64$ \\
7 & Beban Penyisihan Piutang & $8.959 .980,00$ & $51.988 .750,00$ \\
8 & Beban Lain-lain & $39.029 .689 .834,00$ & $23.253 .380 .966,64$ \\
\hline Jumlah
\end{tabular}

Sumber : CaLK RSUD Cimacan, 2016. 
RSUD Cimacan juga menyajikan saldo surplus/defisit dari kegiatan non operasional pada laporan operasionalnya meskipun saldo yang dihasilkan sebesar Rp 0,- terdiri dari surplus penjualan dan defisit penjualan aset tidak lancar. Surplus dan defisit laporan operasional merupakan akumulasi dari komponen-komponen laporan operasional dimana RSUD Cimacan tahun anggaran 2016 mengalami defisit sebesar Rp 19.552.254.026,baik dari transaksi yang dianggarkan melalui anggaran belanja daerah dan pendapatan daerah maupun pendapatan BLUD yang diterima. Dari hasil analisis komparatif yang dilakukan bisa dinyatakan bahwa RSUD Cimacan telah menerapkan laporan operasionalnya sesuai dengan akuntansi dan aturan pada rumah sakit berstatus sebagai BLU penuh.

\section{Laporan Arus Kas}

RSUD Cimacan tidak menyajikan arus kas berdasarkan laporan instansi pemerintah dalam KMK No. 1981/2010 untuk mengetahui arus kas masuk dan arus kas keluar dari kegiatannya, maka dari itu RSUD Cimacan belum sesuai menerapkan keuangan pada arus kas sesuai KMK No. 1981 Tahun 2010 untuk pedoman dan acuan akuntansi BLU rumah sakit. Dalam laporan keuangan menyesuaikam dengan PP No. 71/2010 (Pergantian dari PP No. 24/2005) bahwa komponen-komponen keuangan untuk dijadikan laporan tersusun atas laporan financial dan laporan pelaksanaan anggaran (Budgeting reports) sehingga seluruh komponen yakni laporan realisasi anggaran, laporan perubahan SAL, neraca, laporan operasional, arus kas, LPE dan CaLK. Komponen-komponen laporan keuangan tersebut disajikan oleh setiap entitas pelaporan kecuali laporan arus kas disajikan hanya oleh entitas yang berfungsi sebagai perbendaharaan umum dan laporan SAL disajikan oleh bendahara umum negara dan sebagai entitas pelaporan untuk menyusun laporan keuangan konsolidasiannya (Firdaus, dkk. 2015) dan IAI menganjurkan dalam PSAK Nomor 2 pada ruang lingkup dan kegunaan informasi dari arus kas supaya setiap entitas harus menyusun arus kas yang ditetapkan sesuai dengan persyaratan dan menyajikannya sebagai bagian tidak terpisahkan dari laporan keuangan untuk setiap periode serta memberikan informasi pengelolaan berupa penerimaan dan penggunaan kas, dinyatakan pula merupakan salah satu laporan pokok yang harus disusun untuk mengambil keputusan ekonomi (Wehantouw, 2015).

Laporan BLUD berupa arus kas akan dikonsolidasikan pada laporan arus kas Bendahara Umum Daerah (BUD) seperti transaksi dari pendapatan, belanja, dan pembiayaan yang disahkan oleh BUD, sedangkan laporan realisasi anggaran, neraca, laporan operasional, dan LPE dikonsolidasikan pada laporan entitas akuntansi/entitas pelaporan yang membawahinya, juga dalam penerapannya RSUD Cimacan bukan merupakan fungsi perbendaharaan umum dalam pemerintah daerah kabupaten cianjur, dimana dalam penyajian arus kas dilakukan oleh pemda sebagai BUD maka diperlukan informasi arus kas untuk dikonsolidasikan.

RSUD Cimacan sudah membuat arus kas dalam bentuk laporan berdasarkan SAK ETAP namun tidak membuat berdasarkan SAP sebagai kesesuaian dengan standar yang diikuti seharusnya RSUD Cimacan juga menyajikan laporan arus kas berdasarkan SAP sebagai komponen lengkap dalam laporan keuangan yang disajikan sehingga para peneliti atau pihak yang membutuhkan bisa lebih memahami dan membandingkan arus kas tahun sebelumnya dengan tahun sekarang serta untuk kepentingan konsolidasi.

\section{Catatan atas Laporan Keuangan}

Dalam KMK No. 1981 Tahun 2010 dijelaskan mengenai informasi dalam CaLK yang mencakup antara lain :

a. Pendahuluan

b. Kebijakan akuntansi

c. Penjelasan dari pos-pos neraca

d. Penjelasan dari pos-pos laporan operasional

e. Penjelasan dari pos-pos laporan arus kas

f. Kewajiban kontinjensi

g. Informasi tambahan serta pengungkapan lainnya.

Informasi kuantitatif secara komparatif harus diungkapkan dengan tahun sebelumnya kecuali apabila dinyatakan lain pada PSAK. Informasi dalam CaLK disajikan pada tabel 7 perbandingan CaLK dari laporan keuangan RSUD Cimacan berikut ini : 
Tabel 7: Perbandingan Catatan atas Laporan Keuangan Menurut RSUD Cimacan dan Menurut KMK No. 1981 Tahun 2010

\begin{tabular}{cccc}
\hline No & $\begin{array}{c}\text { Penyajian Laporan keuangan } \\
\text { Menurut KMK }\end{array}$ & $\begin{array}{c}\text { Penyajian Laporan Keuangan } \\
\text { Menurut RSUD Cimacan }\end{array}$ & Sesuai \\
& & $\begin{array}{r}\text { Hasil } \\
\text { Tidak } \\
\text { Sesuai }\end{array}$
\end{tabular}

1 CaLK menyajikan gambaran umum RSUD Cimacan menyajikan rumah sakit berstatus BLU

2 CaLK menyajikan ikhtisar kebijakan akuntansi tertentu yang berisi dasar laporan keuangan yang disusun.

$3 \quad$ CaLK berisi penjelasan dari pos-pos gambaran umum

RSUD Cimacan menyajikan kebijakan akuntansi dan dasar laporan keuangan dalam penyusunannya yang disajikan meliputi neraca laporan operasional, laporan arus sesuai pos-pos laporan kas dan laporan lain yang berkaitan keuangan yang tersaji

Sumber : Data hasil olahan, 2017

Dari tabel 7 bahwa CaLK RSUD Cimacan sesuai dengan KMK No. 1981 Tahun 2010 sebagai pedoman akuntansi Badan Layanan Umum-Rumah Sakit (BLU-RS). RSUD Cimacan membuat dan menyajikan CaLK yang berisi sebagai berikut:

a. Pendahuluan berisi maksud, tujuan dan landasan hukum penyusunan laporan keuangan.

b. Kebijakan akuntansi, ekonomi makro dan pencapaian kinerja APBD.

c. Ikhtisar dan hambatan pencapaian kinerja keuangan.

d. Kebijakan akuntansi berisi entitas pelaporan, basis pengukuran dan akuntansi yang mendasari laporan keuangan yang disusun serta penerapan standar akuntansi pemerintahan.

e. Penjelasan dari pos-pos yang tersaji pada laporan keuangan yaitu LRA, neraca, LO dan LPE.

f. Penjelasan informasi lain.

g. Penutup.

CaLK RSUD Cimacan sebagai BLUD penuh menyajikan informasi kuantitatif dan kualitatif sesuai aturan dari standar KMK No. 1981/2010. Penjelasan dari CaLK RSUD Cimacan tahun 2016 secara lengkap telah menjelaskan informasi yang terkait antara laporan keuangan yang dibuat sehingga dapat dipertanggungjawabkan. Secara keseluruhan informasi yang terdapat dalam CaLK RSUD Cimacan tahun 2016 sudah menjelaskan secara rinci laporan keuangan yang disusun dan disajikan, hanya saja belum terdapat analisis rasio keuangannya.

Analisis yang telah dilakukan terhadap laporan keuangan RSUD Cimacan tahun 2016 dengan standar KMK Nomor

1981/MENKES/SK/XII/2010 merupakan pedoman akuntansi terhadap rumah sakit berstatus BLU menunjukan bahwa secara keseluruhan RSUD Cimacan telah menerapkan laporan keuangan sesuai standar akuntansi akuntansi Badan Layanan Umum-Rumah Sakit (BLU-RS) dalam neraca, laporan operasional/laporan aktivitas, dan CaLK laporan keuangan RSUD Cimacan periode 2016, hanya saja RSUD Cimacan tidak membuat arus kas pada laporan keuangan sesuai dasar SAP dalam PP No. 71/2010. Dari komponen lengkap dalam menyajikan laporan keuangan terdiri dari neraca, laporan operasional, arus kas dan CaLK maka seharusnya RSUD Cimacan menyajikan arus kas dalam bentuk laporan keuangan berdasarkan ketentuan dan aturan yan berlaku.

Dalam KMK No. 1981 menyebutkan tujuan laporan keuangan untuk menyediakan informasi berhubungan dengan keuangan sehingga memberi manfaat bagi para pengguna laporan keuangan dalam keputusan yang diambil secara rasional, seperti : pemberi bantuan (donatur), investor, kreditor, otoritas pengawasan, pemerintah dan masyarakat. Adapun manfaat bagi pengguna informasi keuangan, diantaranya :

1. Bagi pimpinan RSUD; pimpinan RSUD sangat membutuhkan informasi keuangan untuk memprediksi prospek layanan yang diberikan rumah sakit untuk masa selanjutnya sehingga pengambilan keputusan lebih berkualitas dan tepat sasaran. Pimpinan RSUD dapat menilai sejauh mana RSUD membiayai sendiri kegiatan pelayanan, pembangunan dan pemerinthan dilihat dari laporan keuangan 
sesuai rasio kemandirian, untuk melihat tingkat kemandirian kinerja keuangan rumah sakit, mengefektifitaskan kinerja keuangan, dan mengefisienkan kinerja keuangan RSUD (Antari, 2014).

2. Bagi donatur (pemberi bantuan); menyediakan informasi keuangan yang relevan dalam memenuhi kepentingan pemberi bantuan, memberikan informasi keuangan yang baik untuk para penyumbang agar tidak menghilangkan kepercayaan dan mengambil keputusan dalam menghentikan pendanaan terhadap organisasi nirlaba yang dikelolanya (Sulistiyoningsih, 2013).

3. Bagi investor; investor tentunya membutuhkan informasi yang bisa dijadikan referensi dalam mengambil keputusan. Pelaporan keuangan berdasarkan GCG untuk memberi kepercayaan kepada investor. Dengan adanya kepercayaan dari investor, maka investor akan menanamkan investasinya kepada instansi/perusahaan (Simadibrata, 2012).

4. Bagi kreditor; kreditor dapat mengetahui informasi kondisi keuangan, informasi kondisi ekonomi, informasi kepatuhan terhadap aturan, informasi kinerja, informasi rencana anggaran dan informasi naratif dalam keuangan (Yentifa, 2010).

5. Bagi otoritas pengawasan; otoritas pengawasan (seperti SPI, BPK dan auditor) bisa memberikan saran terhadap peningkatan kualitas laporan keuangan, harus lebih memperhatikan penerapan SPI dan SAP dengan melakukan peningkatan kualitas SDM yang benar-benar memiliki kompetensi keahlian dan integritas yang tinggi, sehingga paham terhadap standar dan aturan yang sudah ditetapkan (Susilawati dan Riana, 2014).

6. Bagi instansi pemerintah; informasi keuangan dijadikan kebenaran serta acuan dalam penetapan jumlah pajak. Instansi daerah tentunya selalu dalam pengawasan pemerintah baik daerah maupun pusat sehingga memberi kemudahan dalam mengendalikan dan mengawasi keuangan. Dari suatu informasi keuangan instansi, pemerintah bisa menetapkan pajak yang perlu dibayar oleh organisasi bersangkutan sesuai yang ditetapkan (Irfani dan Dahria, 2009).
7. Bagi masyarakat; laporan keuangan dapat membantu orang-orang dalam penyediaan informasi yang berkecenderungan dan perkembangan keberlangsungan rumah sakit serta aktivitas pelayanannya serta memberikan informasi ruang kebutuhan tenaga kerja, memungkinkan untuk menerima sebuah lamaran pekerjaan dari masyarakat dan penunjang kehidupan ekonomi masyarakat, mengukur informasi keuangan sudah sejauh mana dalam meningkatkan kemapuan instansi pemerintah dalam mencapai kinerja bagi kesejahteraan masyarakat, menjadi penilaian tingkat akuntabilitas pemerintah dapat lebih komprehensif serta mengukur indeks akuntabilitas lembaga pemerintah (Apriyanti, dkk. 2015).

Keuntungan status BLUD bagi rumah sakit daerah dengan diterapkannya pedoman standar akuntansi BLU-RS yang dikeluarkan Menteri Kesehatan dalam KMK Nomor 1981/MENKES/SK/XII/2010, yaitu :

1. Pengelolaan keuangan terhadap RSUD menjadi lebih trasnparan dengan penyajian dan pelaporan menggunakan SAK dalam memberikan informasi keuangan tentang neraca, laporan operasional/aktivitas, arus kas dan CaLK.

2. Memudahkan penyusunan juga penyajian informasi keuangan sesuai pedoman akuntansi yang berlaku.

3. Mengembangkan laporan keuangan sesuai akuntansi pemerintahan basis akrual.

4. Penggunaan akuntansi untuk mempermudah dalam mengendalikan dan mengawasi keuangan oleh pemerintah.

5. Pendapatan rumah sakit dapat digunakan secara langsung meski tidak disetorkan hanya dilaporkan ke departemeen keuangan.

6. Mengembangkan pelayanan dengan tersedianya dana kegiatan operasional rumah sakit.

7. Masih bisa mendapatkan subsidi pemerintah seperti biaya operasional, modal dan biaya investasi.

8. Meningkatkan kualitas tenaga kerja sesuai dengan profesionalitasnya.

\section{KESIMPULAN}

1. Penyajian laporan keuangan RSUD Cimacan berstatus BLUD penuh secara garis besar sesuai dengan KMK No.1981 tahun 2010 sebagai pedoman akuntansi BLU-RS, tetapi 
belum secara penuh dalam laporan keuangan yang disajikan sebagai BLUD dikarenakan RSUD Cimacan hanya menyajikan Realisi Anggaran, Neraca, Operasional, Perubahan Ekuitas dan CaLK namun belum menyajikan informasi arus kas yang disajikan sesuai basis SAP sesuai PP No.71/ 2010 untuk entitas ke pemda sebagai entitas pelaporan dalam hal konsolidasi.

2. Pelaporan keuangan RSUD Cimacan berstatus BLUD penuh belum sesuai dengan laporan keuangan BLU-RS dikarenakan belum menyajikan informasi arus kas sebagai komponen pelengkap laporan keuangan sebagai BLU rumah sakit, juga sebagai kebutuhan untuk pihak berkepentingan.

\section{DAFTAR PUSTAKA}

Antari, Gusti Ayu Yuni, 2016, Analisis Laporan Keuangan sebagai Dasar Menilai Kinerja Keuangan pada RSUD Bangli, Jurnal Jurusan Pendidikan Ekonomi (JJPE) Volume 7 No.2 tahun 2016, Universitas Pendidikan Ganesha, Singaraja.

Apriyanti, Dwi, Harpanto Guno Sabanu, dan Fahrizal Noor., 2015, Penilaian Indeks Akuntabilitas Instansi Pemerintah, Jurnal Tata Kelola \& Akuntabilitas Keuangan Negara Volume 1 No.1, Juli 2015 : 21-42, BPK, Indonesia.

Arikunto, S, 2010, Prosedur Penelitian Suatu Pendekatan Praktek, Cetakan Ke 12, Edisi Revisi kelima, Rineka Cipta, Jakarta.

Belkaoui, Ahmed Riahi, 2006, Teori Akuntansi, Buku 1, Edisi Kelima, Salemba Empat, Jakarta.

Eriotis., Nikolaos, Fillipos Stamatiadis dan Dimitrios Vasiliou, 2009, Assessing Accrual Accounting Reform in Greek Public Hospitals: an Empirical Investigation, International Journal of Economic Sciences and Applied Research Volume 4 Issued 1:153-184, Munich Personal RePEc Archive (MPRA) Paper No. 30246, diposkan 24 April 2011 04:55 UT, University Of Athens, Greece.

Firdaus, Dahlia, Djoko Sigit Sayogo, dan Sri Wahjuni Latifah,2015, Evaluasi Penerapan PP No 71/201 Tentang SAP Berbasis Akrual : Studi Kasus di Pemda Nganjuk, Jurnal Akuntansi dan Investasi
Volume 16 No.1, Januari 2015, Universitas Muhammadiyah, Malang.

Ikatan Akuntan Indonesia, 2009, Pernyataan Standar Akuntansi Keuangan, Jakarta.

Irfani, Halizah dan Muhammad Dahria, 2009, Peran Akuntansi dalam Operasi Bisnis, Jurnal Saintikom volume 7 No.2, Agustus 2009, LPPM-STMIK Triguna Dharma, Medan.

Kasmir, 2011, Analisis Laporan Keuangan, Cetakan Keempat, PT.Raja Grafindo Persada, Jakarta.

Keputusan Menteri Kesehatan Nomor 1981 Tahun 2010, Tentang Pedoman Akuntansi Badan Layanan UmumRumah Sakit.

Kieso,D.E, Weygant, JJ, dan Warfield, T.D, 2007, Accounting Principle : Pengantar Akuntansi, Salemba Empat, Jakarta.

Mardiasmo, 2010, Akuntansi Sektor Publik, Andi, Yogyakarta.

Munawir, 2007, Analisa Laporan Keuangan, Edisi Keempat, Cetakan Ke 14, Liberty, Yogyakarta.

Peraturan Menteri Keuangan Nomor 76/PMK.05/2008, Tentang Pedoman Akuntansi dan Pelaporan Keuangan Baadan Layanan Umum.

Peraturan Pemerintah Nomor 23 Tahun 2005, Tentang Pengelolaan Keuangan Badan Layanan Umum.

Peraturan Pemerintah Nomor 71 Tahun 2010, Tentang Standar Akuntansi Pemerintah.

Rosnidah, Ida, Juwenah, dan Apri Dwi Astuti, 2016, Identifikasi Eksiting Sistem Akuntansi BLUD pada RSUD Kabupaten Cirebon, Jurnal Riset dan Akuntansi Keuangan Volume 4 No. 2, pp : 32 - 46. PISSN : 23381507.

Santi, Elsafitri, dan Irda Rosida, 2009, Implementasi dan Kendala Penerapan Pengelolaan Keuangan BLU, Jurnal Akuntansi \& Manajemen Volume 4 No.2, Desember 2009, ISSN 1858-3687 hal 4154, Politeknik Negeri Padang.

Simadibrata, Theresia Adelia, 2012, Peranan Good Corporate Governance Terhadap Kualitas Pelaporan Keuangan dan Kepercayaan Investor, Jurnal Ilmiah Mahasiswa Akuntansi Volume 1 No.4, Juli 2012, Unika Widya Mandala, Surabaya. 
Sujarweni, V. Wiratna, 2014, Metodologi Penelitian, Pustaka Baru Press, Yogyakarta.

Sulistiyoningsih, Dewi, dan Ikhsan Budi Riharjo, 2013, Implementasi PSAK Nomor 45 dalam Pelaporan Keuangan pada Yayasan Lembaga Pendidikan Zainuddin, Jurnal Ilmu dan Riset Akuntansi Volume 2 No.1, STIESA Surabaya.

Surianto dan Laksono Trisnantoro, 2013, Evaluasi Penerapan Kebijakan dan Penerapan BLUD di RSUD Undata Provinsi Sulawesi Tengah, Jurnal Kebijakan Kesehatan Indonesia, Volume 2 No.1, Maret 2013, Universitas Gadjah Mada, Yogyakarta.

Susilawati dan Dwi Septiana Riana, 2014, SAP dan SPI sebagai Anteseden Kualitas Laporan Keuangan Pemerintah Daerah, Study and Accounting Research Volume XI No. 1, ISSN: 1693-4482, STIE STEMBI, Bandung.

Sutrisno, 2007, Manajemen Keuangan (Teori, Konsep dan Aplikasi), Edisi Kesatu, Cetakan Kelima, Ekonisia, Yogyakarta.

Undang-Undang Nomor 1 Tahun 2004, Tentang Perbendaharaan Negara.

Undang-Undang Nomor 44 Tahun 2009, Tentang Rumah Sakit.

Wehantouw, Andre B, dan Jantje J. Tinangon, 2015, Analisis Laporan Arus Kas Operasi, Investasi dan Pendanaan pada PT. Gudang Garam Tbk, Jurnal EMBA Volume 3 No.1, Maret 2015, hal 806-817, Universitas Sam Ratulangi, Manado.

Widiastutik, Niken, Susilawati, R. Anastasia Endang dan Abdul Halim, 2015, Analisis Penerapan PSAK Nomor 45 dan PMK Nomor 76/PMK.05/2008 Tentang Pelaporan Keuangan Organisasi Nirlaba pada Unit Bisnis Griya Brawijaya Universitas Brawijaya Berstatus BLU, Jurnal Riset Mahasiswa Akuntansi (JRMA), Universitas Kanjuruhan.

Yentifa, Armel, Yurniwati, dan Suhanda, 2010, Kebutuhan Investor dan Kreditor atas Informasi dalam Pelaporan Keuangan Pemerintah Daerah, Artikel Simposium Nasional Akuntansi XIII Purwokerto 2010, Universitas Jenderal Soedirman, Purwokerto.

http: iaiglobal.or.id/v03/standar-akuntansikeuangan/sak diakses pada 23 Februari 2017 jam 13.54 WIB http://jabar.bnn.go.id/lembagarehabilitasi/rsud-cimacan diakses pada 14 Oktober 2016 jam 19.54 WIB

http://mashani77.net/2016/03/30/mengapamasih-ada-rsud-yang-belummenjalankan-pppk-blud/ diakses pada 27 Maret 2017 jam 19.25 WIB 